\title{
COMMENT
}

\section{Response to an article by Hamilton et al. on 'Effects of colony stimulating factor-1 on human extravillous trophoblast growth and invasion'}

\author{
M Sullivan and $\mathbf{M} \mathbf{P}$ Lewis \\ Institute of Obstetrics \& Gynaecology, Department of Maternal \& Fetal Medicine, Imperial College School of Medicine, \\ Queen Charlotte's and Chelsea Hospital, Goldhawk Road, London W6 OXG, UK
}

We wish to comment on the article by Hamilton et al. 1998.

Table 1 shows the similarities and differences between the observations made in the two papers (Lewis et al. 1996, Hamilton et al. 1998) which have investigated the roles of colony-stimulating factor-1 (CSF-1) and its receptor (c-fms) in human extravillous cytotrophoblast (EVCT). Both types of EVCT show the components of a CSF-1/ c-fms autocrine loop, and it is clear that there is no role for CSF-1 in controlling EVCT invasion (Table 1). However, in primary cells (designated EVT), CSF-1 was a positive regulator of cell proliferation (Hamilton et al. 1998), whereas in immortalised TCL-1 cells (and in BeWo choriocarcinoma) CSF-1 appeared to be an inhibitor of such proliferation (Lewis et al. 1996).

There are a number of factors which may contribute to this difference in the data obtained, but we must firstly point out that Hamilton et al. have not reported our previous data accurately. In the last paragraph of the discussion they state "... those cells (TCL-1 cells) also exhibited an autocrine CSF-1 loop which enhanced proliferation." This is the opposite of what we reported (Lewis et al. 1996), that "Proliferation of TCL-1 cells .... was elevated in response to treatment with a CSF-1 neutralising antibody." (abstract). We therefore suggested that
CSF-1 may be a differentiation or maturation factor which suppresses the proliferation of trophoblasts (Aplin 1991).

Possible explanations for the differences in effects of CSF-1 include the following:

(1) EVT were obtained by culture of adherent cells and explants from minced first trimester villi (Hamilton et al. 1998), whereas TCL-1 were from chorionic membranes and immortalised with the SV40 large-T antigen (Lewis et al. 1996). There may be a change in trophoblast response to CSF-1 depending on gestational age, intrauterine location or, as described by Hamilton et al., the fact that TCL-1 were immortalised.

(2) TCL-1 cells did not respond to CSF-1, and the levels of CSF-1 released were sufficient to saturate the c-fms receptor (Lewis et al. 1996). The release of CSF-1 from EVT cells was not quantified, but the response of the cells to CSF-1 in vitro suggested that the receptor would not be saturated. The quantity of CSF-1 needed $(62.5 \mathrm{ng} / \mathrm{ml}$, or $\sim 750 \mathrm{nM})$ is higher than the accepted affinity of the c-fms receptor $(\sim 30 \mathrm{nM})$.

(3) The proliferation indices of the cells seem to differ markedly. In serum-free medium, EVT incorporated 400-1000 c.p.m./6 h (Hamilton et al. 1998). TCL-1 cells incorporated about $300000 \mathrm{dpm} / \mathrm{h}$ (our unpublished data), a rate substantially greater. The EVT cells were examined on day 5 of culture, in contrast to TCL-1 cells

Table 1 Comparison between results from Hamilton et al. 1998 and Lewis et al. 1996

\begin{tabular}{|c|c|c|c|}
\hline & Hamilton et al. 1998 & Lewis et al. 1996 & Agreement \\
\hline $\begin{array}{l}\text { Cell type } \\
\text { CSF-1 } \\
\text { c-fms (mRNA) }\end{array}$ & $\begin{array}{l}\text { Extravillous trophoblast } \\
\text { Yes (mRNA) } \\
\text { Yes }\end{array}$ & $\begin{array}{l}\text { Extravillous trophoblast } \\
\text { Yes }(10-30 \mathrm{pM} \text { protein }) \\
\text { Yes }\end{array}$ & $\begin{array}{l}\text { Yes } \\
\text { Yes* } \\
\text { Yes }\end{array}$ \\
\hline $\begin{array}{l}\text { Addition of: } \\
\text { CSF-1 } \\
\text { Ab to CSF-1 } \\
\text { CSF-1, Ab to CSF-1, Ab to c-fms }\end{array}$ & $\begin{array}{l}\text { Growth increased } \\
\text { Growth decreased } \\
\text { In vitro invasion and balance between } \\
\text { MMPs and TIMPs unaffected }\end{array}$ & $\begin{array}{l}\text { No effect } \\
\text { Growth increased } \\
\text { MMP activity unaffected }\end{array}$ & $\begin{array}{l}\text { No } \\
\text { No } \\
\text { Yes }\end{array}$ \\
\hline
\end{tabular}

*This may be an important point. If the EVT cells released much lower levels of CSF-1, which did not saturate the receptor, effects of exogenous CSF-1 would be expected. This still would not exlain why CSF-1 was a positive effector in Hamilton et al. 1998 and a negative effector in Lewis et al. 1996. 
(days 2-4 of culture). Our unpublished data suggest that TCL-1 proliferation decreased markedly in confluent populations, and this may contribute to the difference in proliferation obtained.

There must be a major difference in the coupling of $\mathrm{c}-\mathrm{fms}$ to second messenger pathways in these two cell-types, such that in EVT the link is to transcription factors (Hamilton et al. 1998), and in TCL-1 cells to differentiation pathways (Lewis et al. 1996). The cells described in these two papers may together provide useful models for the further study of the role of the CSF-1/c-fms axis in EVCT.

\section{References}

Aplin JD 1991 Implantation, trophoblast differentiation and haemochorial placentation: mechanistic evidence in vivo and in vitro. Journal of Cell Science 99 681-692.

Hamilton GS, Lysiak JJ, Watson AJ \& Lala PK 1998 Effects of colony stimulating factor-1 on human extravillous trophoblast growth and invasion. Journal of Endocrinology 159 69-77.

Lewis MP, Clements M, Takeda S, Kirby PL, Seki H, Lonsdale LB, Sullivan MHF, Elder MG \& White JO 1996 Partial characterisation of an immortalised trophoblast cell-line, TCL-1, which possess a CSF-1 autocrine loop. Placenta 17 137-146.

\title{
REPLY FROM AUTHOR
}

\section{Possible explanation for opposite responses of EVT and TCL-1 cells to endogenous CSF-1}

\author{
P K Lala \\ Department of Anatomy and Cell Biology, University of Western Ontario, London, Ontario, Canada N6A 5C1
}

We apologize for inaccurately quoting Lewis et al. (1996) in our recent paper by Hamilton et al. (1998) as CSF-1 having an autocrine growth-stimulating loop in their immortalized extravillous trophoblast TCL-1 cell line, similar to that observed by us (Hamilton et al. 1998) in normal extravillous trophoblast (EVT) cells.

In their study (Lewis et al. 1996), a growth stimulation was noted in the presence of CSF-1 neutralizing antibody indicating an anti-proliferative/differentiation-inducing role of endogenous CSF-1 for TCL-1 cells. The table included in the article above accurately compares the results of the two studies. In spite of the fact that both normal EVT cells (Hamilton et al. 1998) as well as TCL-1 cells (Lewis et al. 1996) express CSF-1 receptor and produce CSF-1 (although at different levels), the reasons for opposite responses of these cells to endogenous CSF-1 remain unclear. The most likely explanation is the genetic alterations induced by SV40 Tag immortalization in the case of TCL-1 cells. We have also derived two independently immortalized EVT cell lines, HTR-8/SVneo (Graham et al. 1993) and RSVT2/C (Khoo et al. 1998), by introducing SV40 Tag gene into a normal, mortal EVT cell line HTR-8, which was one of the cell lines used in our CSF-1 study (Hamilton et al. 1998). Similar to TCL-1 cells (Lewis et al. 1996), the proliferation rate of HTR-8/ $\mathrm{SV}_{\text {neo }}$ cells is much higher than that of HTR-8 cells (Graham et al. 1993) and remains unaltered in the presence of exogenous CSF-1 (author's unpublished data). However, the possible effect of endogenous CSF-1 on prolifer- ation of the cells remains to be tested by addition of CSF-1 neutralizing antibody or CSF-1 receptor blocking antibody. These immortalized extravillous trophoblast cell lines show a premalignant phenotype (Khoo et al. 1998a,b) and present as excellent tools for studies of molecular/ genetic mechanisms underlying trophoblastic tumor progression.

\section{References}

Graham CH, Hawley TS, Hawley RG, MacDougall JR, Kerbel RS, Khoo N \& Lala PK 1993 Establishment and characterization of first trimester human trophoblast cells with extended life span. Experimental Cell Research 206 204-211.

Hamilton GS, Lysiak JJ, Watson AJ \& Lala PK 1998 Effects of colony stimulating factor-1 on human extravillous trophoblast growth and invasion. Journal of Endocrinology 159 69-77.

Khoo NKS, Bechberger JF, Shepherd TR, Bond SL, McCrae KR, Hamilton GS \& Lala PK 1998a SV40 Tag transformation of normal invasive trophoblast results in a premalignant phenotype. I. Mechanisms responsible for hyperinvasiveness and resistance to antiinvasive action of TGF $\beta$. International Journal of Cancer $\mathbf{7 7}$ 429-439.

Khoo NKS, Zhang Y, Bechberger JF, Bond SL, Hum K \& Lala PK $1998 b$ SV40 Tag transformation of normal invasive trophoblast results in a premalignant phenotype. II. changes in gap junctional intercellular communication. International Journal of Cancer $\mathbf{7 7}$ 440-448.

Lewis MP, Clements M, Takeda S, Kirby PL, Seki H, Lonsdale LB, Sullivan MHF, Elder MG A White JO 1996 Partial characterization of an immortalized trophoblast cell line, TCL-1, which process a CAF-1 autocrine loop. Placenta 17 137-146. 